\title{
KARAKTERISTIK DAN PERSEPSI KENYAMANAN WISATAWAN MANCANEGARA DI PANTAI KUTA BALI
}

\author{
I Made Juniawan \\ Ni Made Oka Karini \\ Luh Gede Leli Kusuma Dewi \\ june.awan94@yahoo.com \\ PS. S1 Industri Perjalanan Wisata \\ Fakultas Pariwisata UNUD
}

\begin{abstract}
Based the bad environment of Kuta, such as narrow roads, traffic jam, and less of parking area, also less of security sector that happens to prevent crime like a terrorism, murder, or theft. Therefore, this research done to know how the characteristics of foreign tourist who come to Kuta, and whether the tourists still feel comfortable, with the negative impact that arising from tourism activities at Kuta. The method of research using quantitative and qualitative descriptive, with Purposive Sampling as sampling technique, also Sampling Quota and Incidental Sampling as technique taking a sample. By utilize observation, questioners, and document study as method collecting of data. Characteristics of foreign tourists who come to Kuta beach dominated by male tourists with age 21-25 years. Almost of tourists who visiting Kuta has the occupation as student or college. Where, 33\% of tourists coming from Australia. Base on final systematic calculation, obtain the final result 3.66, which entered into good category. Therefore, if make a connecting the final result with the Table Interval Comfort Level Criteria, get the conclusion that perception the comfort of foreign tourists at Kuta beach Bali entered into comfortable category. There are factors that obtain greatest value that is Natural resources/climate, Relationship with local people, Beauty, Cleanness, and Relationship between the tourists.
\end{abstract}

\section{Keywords: Characteristic, Comfort, Foreign tourist, Kuta beach Bali.}

\section{PENDAHULUAN}

Kenyamanan selalu menjadi hal yang sangat penting dalam kegiatan pariwisata. Kenyamanan adalah salah satu faktor yang paling berpengaruh pada keputusan wisatawan untuk berkunjung ulang ke destinasi yang bersangkutan. Kegiatan pariwisata di Kuta, telah memberikan pengaruh yang cukup besar terhadap aspek-aspek sekitar.

Terlepas dari dampak positif yang ditimbulkan seperti meningkatnya pendapatan daerah ataupun pendapatan dari masyarakat lokal, kegiatan pariwisata di Kuta juga memberikan dampak negatif terhadap beberapa aspek seperti aspek lingkungan, sosial, maupun aspek lainnya. Sehingga dampak-dampak negatif yang timbul akibat dari kegiatan pariwisata di Kuta sebagai salah satu daya tarik wisata terkenal di Bali, akan berpengaruh kepada wisatawan yang berkunjung, dan salah satunya akan berpengaruh terhadap kenyamanan wisatawan.

Oleh karena itu, jurnal ini membahas mengenai apakah wisatawan yang berkunjung ke Kuta masih merasa nyaman, serta bagaimanakah karakteristik wisatawan mancanegara yang berkunjung ke Pantai Kuta. Meski banyaknya dampak negatif yang timbul dari kegiatan pariwisata di Kuta, Pantai Kuta masih menjadi salah satu daya tarik wisata terkenal di Bali.

Dengan menggunakan teori dari Katharine Kolcaba dalam "Comfort theory and its application to pediatric nursing" (2005), yaitu kenyamanan mesti dipandang secara holistik yang mencakup empat aspek antara lain : 
1. Fisik yaitu rasa nyaman yang berhubungan dengan sentuhan atau apa yang dirasakan oleh badan seseorang/sensasi tubuh.

2. Lingkungan yaitu rasa nyaman yang berhubungan dengan lingkungan, atau latar belakang pengalaman eksternal manusia seperti cahaya, bunyi, temperatur, warna, dan unsur alamiah lainnya.

3. Sosial yaitu rasa nyaman yang berhubungan dengan hubungan interpersonal, keluarga, dan hubungan sosial atau masyarakat.

4. Psikospiritual yaitu rasa nyaman yang berhubungan dengan kewaspadaan internal dalam diri sendiri yang meliputi harga diri, konsep diri, seksualitas, makna kehidupan, hingga hubungan terhadap kebutuhan lebih tinggi.

Disesuaikan dengan teori milik Rustam Hakim (2014), yang menyatakan beberapa faktor yang mempengaruhi kenyamanan antara lain : 1)Sirkulasi, 2)Daya alam/iklim, 3)Kebisingan, 4)Aroma atau bau-bauan, 5)Bentuk, 6)Keamanan, 7)Kebersihan, 8)Keindahan, 9)Penerangan.

\section{METODE PENELITIAN}

Lokasi penelitian ini terletak di Daya Tarik Wisata Pantai Kuta. Tepatnya di Kelurahan Kuta, Kecamatan Kuta, Kabupaten Badung, Bali. Lokasi ini memiliki jarak 1,5 $\mathrm{km}$ dari Bandara Internasional Ngurah Rai Bali, dan sekitar 25 menit dari pusat kota Denpasar. Lokasi ini terletak di selatan Pulau Bali, di arah barat dari Ibu Kota Denpasar.

Metode penelitian menggunakan kuantitatif dan kualitatif deskriptif, dengan Purposive Sampling sebagai teknik penentuan sampel. Untuk pengambilan sampel menggunakan teknik Insidental Sampling, dan Sampling Kuota untuk menentukan besarnya jumlah sampel. Sehingga jumlah sampel yang ditetapkan yaitu wisatawan mancanegara yang berkunjung ke Pantai Kuta Bali sebanyak 100 orang. Teknik pengumpulan data menggunakan observasi, kuesioner, dan dokumen.

\section{HASIL}

Pantai Kuta adalah salah satu pantai tercantik dan terpadat di Bali. Pantai ini berada di sebelah Barat Daya dari Pulau Bali tepatnya di Kelurahan Kuta Kecamatan Kuta
Kabupaten Badung. Sebelum menjadi daya tarik wisata seperti sekarang ini, pada awalnya Kuta merupakan sebuah pelabuhan dagang dimana masyarakat lokal menjajakan produk/hasil bumi yang dimilikinya untuk dijual kepada pembeli dari luar Bali.

Pelabuhan dagang ini mulanya dibangun oleh seorang pedagang yang datang dari Denmark, dimana ia merasa tertarik dengan peluang perdagangan di wilayah Kuta. Sehingga semenjak saat itu banyak pelaut Eropa yang berlabuh di Kuta. Seiring dengan perkembangannya banyak didirikan penginapan di sekitaran pantai dan hingga saat ini Pantai Kuta telah menjadi ikon dari pariwisata Bali.

Pantai yang memiliki panjang 1,5 kilometer ini dikelilingi oleh berbagai daya tarik wisata lain seperti pasar seni, penangkaran penyu, dan pantai-pantai lainnya. Disepanjang pantai ini juga terdapat berbagai sarana pariwisata seperti hotel, villa, restoran, bar, spa, art shop, information center dan pusat perbelanjaan lainnya. Sedangkan di pantainya sendiri terdapat beberapa fasilitas yang dapat dinikmati oleh pengunjung seperti tempat parkir di sepanjang Jalan Pantai Kuta,kamar mandi (termasuk toilet dan ruang ganti), payung pantai, kursi panjang untuk berjemur, tempat penjualan makanan dan minuman, serta penyewaan papan surfing.

Berdasarkan dari hasil penyebaran kuesioner terhadap 100 orang responden yang dalam hal ini merupakan wisatawan mancanegara, diketahui bahwa karakteristik wisatawan mancanegara yang berkunjung ke Pantai Kuta Bali berdasarkan jenis kelamin adalah wisatawan laki-laki sebanyak 52\% dan wisatawan perempuan $48 \%$. Karakteristik berdasarkan rentang umur/usia didominasi oleh wisatawan dengan rentang umur 21-25 tahun, dengan persentase $42 \%$, dan yang terendah wisatawan dengan rentang umur 36-40 tahun dengan persentase 4\%. Karakteristik berdasarkan pekerjaan didominasi oleh wisatawan dengan latar belakang pekerjaan sebagai Pelajar/Mahasiswa sebanyak 41\%. Karakteristik berdasarkan daerah asal atau kebangsaan didominasi oleh wisatawan yang berasal dariAustralia dengan jumlah kunjungan sebesar 33 orang (33\%). Disusul oleh Inggris di posisi 
kedua dengan perolehan sebesar 20 orang (20\%). Sedangkan wisatawan asal Perancis di posisi ketiga dengan jumlah kunjungan sebesar 12 orang atau dengan persentase $12 \%$.

Motivasi wisatawan mancanegara berkunjung ke Pantai Kuta Bali didominasi oleh motivasi untuk memenuhi kebutuhan fisik atau Physical Motivation dengan persentase sebanyak 103\%. Motivasi untuk mendapatkan Status atau Prestise yaitu sebanyak 17\%. Sedangakan motivasi untuk menemui kerabat atau hubungan Interpersonal yaitu sebanyak $2 \%$.

Adapun persepsi wisatawan mancanegara mengenai kenyamanan di Pantai Kuta Bali, dapat dilihat pada Tabel 1.

Tabel 1. Persepsi Kenyamanan Wisatawan Mancanegara di Pantai Kuta Bali

\begin{tabular}{|c|c|c|c|c|}
\hline Sub-Variabel & Indikator & Hasil & Rata-rata & Nilai \\
\hline \multirow{3}{*}{ Fisik } & Bentuk & 3.64 & \multirow{3}{*}{3.53} & \multirow{3}{*}{ Baik } \\
\hline & Kebisingan & 3.36 & & \\
\hline & Aroma/ bau-bauan & 3.58 & & \\
\hline \multirow{4}{*}{ Lingkungan } & Sirkulasi & 3.19 & \multirow{4}{*}{3.76} & \multirow{4}{*}{ Baik } \\
\hline & Daya alam/ iklim & 4.15 & & \\
\hline & Kebersihan & 3.79 & & \\
\hline & Keindahan & 3.94 & & \\
\hline \multirow{2}{*}{ Sosial } & Hubungan masyarakat & 3.96 & \multirow{2}{*}{3.86} & \multirow{2}{*}{ Baik } \\
\hline & Hubungan wisatawan & 3.73 & & \\
\hline \multirow{2}{*}{ Psikospiritual } & Keamanan & 3.38 & \multirow{2}{*}{3.42} & \multirow{2}{*}{$\begin{array}{c}\text { Cukup } \\
\text { Baik }\end{array}$} \\
\hline & Ketenangan & 3.47 & & \\
\hline \multicolumn{2}{|c|}{ Hasil Akhir } & \multicolumn{2}{|c|}{3.66} & Baik \\
\hline
\end{tabular}

Berdasarkan Tabel 1 dapat diketahui bahwa persepsi kenyamanan berdasarkan faktor fisik yang didalamnya terdapat indikator bentuk (3.64), kebisingan (3.36), dan aroma/bau-bauan (3.58), memperoleh rata-rata sebesar 3.53 sehingga masuk ke dalam kategori baik. Persepsi kenyamanan berdasarkan faktor lingkungan yang didalamnya terdapat indikator sirkulasi (3.19), daya alam/iklim (4.15), kebersihan (3.79), dan keindahan (3.94), memperoleh rata-rata sebesar 3.76 sehingga masuk ke dalam kategori baik. Persepsi kenyamanan berdasarkan faktor sosial yang didalamnya terdapat indikator hubungan dengan masyarakat lokal (3.96), dan hubungan antar wisatawan (3.73), memperoleh rata-rata sebesar 3.86 sehingga masuk ke dalam kategori baik. Persepsi kenyamanan berdasarkan faktor psikospiritual yang didalamnya terdapat indikator keamanan (3.38), dan ketenangan (3.47), memperoleh rata-rata sebesar 3.42 sehingga masuk ke dalam kategori cukup. Oleh karena itu, dapat diketahui bahwa persepsi kenyamanan wisatawan mancanegara yang berkunjung ke
Pantai Kuta saat ini masuk ke dalam kategori baik, dengan nilai rata-rata sebesar 3.66.

\section{PEMBAHASAN}

Karakteristik wisatawan mancanegara yang berkunjung atau berlibur ke Pantai Kuta Bali didominasi oleh kunjungan wisatawan laki-laki dengan rentang umur 21-25 tahun. Mayoritas dari wisatawan mancanegara yang berkunjung ke Pantai Kuta saat ini, memiliki latar belakang pekerjaan sebagai Pelajar/Mahasiswa. Dimana, wisatawan yang mendominasi jumlah kunjungan wisatawan mancanegara ke Pantai Kuta Bali yaitu berasal dari Negara Australia.

Hampir seluruh wisatawan mancanegara yang dijadikan sebagai responden memiliki motivasi berkunjung ke Pantai Kuta adalah untuk memenuhi kebutuhan fisiknya. Sebanyak $103 \%$ responden memiliki motivasi berkunjung untuk menyegarkan tubuh dan pikiran mereka, bertujuan untuk kesehatan, olahraga, ataupun untuk bersenang-senang. Namun, dalam data yang telah diperoleh tidak ditemukan satu wisatawan pun yang memiliki motivasi untuk mengenal budaya, khususnya 
budaya di Kuta. Hal ini dikarenakan, Kuta tidak dikenal karena budayanya melainkan lebih dikenal sebagai salah satu daya tarik wisata pantainya.

Persepsi wisatawan mancanegara mengenai kenyamanan berdasarkan faktor fisik atau rasa nyaman yang berhubungan dengan sentuhan atau apa yang dirasakan oleh badan wisatawan di Pantai Kuta adalah Nyaman. Persepsi wisatawan mancanegara mengenai kenyamanan berdasarkan faktor lingkungan atau rasa nyaman yang berhubungan dengan keadaan sekitar yang diamati, dialami, dan dirasakan langsung oleh wisatawan di Pantai Kuta adalah Nyaman.

Persepsi wisatawan mancanegara mengenai kenyamanan berdasarkan faktor sosial atau rasa nyaman yang berhubungan dengan hubungan interpersonal, interaksi dengan masyarakat lokal dan hubungan sosial lainnya di Pantai Kuta adalah Nyaman. Persepsi wisatawan mancanegara mengenai kenyamanan berdasarkan faktor psikospiritual atau rasa nyaman yang berhubungan dengan kewaspadaan internal dalam diri sendiri yang meliputi kepuasan batin, seksualitas, dan makna kehidupan di Pantai Kuta adalah Cukup Nyaman.

Berdasarkan hasil perhitungan akhir yang dilakukan secara sistematis, memperoleh hasil akhir dengan nilai rata-rata sebesar 3.66, yang memiliki arti baik. Jika ditarik hasil akhir dan dihubungkan dengan Tabel Interval Kriteria Tingkat Kenyamanan, dapat kesimpulan bahwa tingkat kenyamanan wisatawan mancanegara di Pantai Kuta Bali masuk ke dalam kategori Nyaman.

Terdapat beberapa indikator yang memperoleh penilaian rendah, sehingga mengurangi kenyamanan wisatawan mancanegara di Pantai Kuta Bali. Indikator tersebut ialah keamanan, kebisingan, dan sirkulasi sebagai yang terendah. Sirkulasi yang dimaksud dalam hal ini ialah akses ke Daya Tarik Wisata Pantai Kuta (situasi lalu intas), dan juga kemudahan wisatawan dalam memarkirkan kendaraan.

Namun, meskipun terdapat beberapa indikator yang dapat mengurangi kenyamanan wisatawan mancanegara di Pantai Kuta, wisatawan mancanegara yang berkunjung atau berlibur di Pantai Kuta masih tetap merasa nyaman. Hal ini dikarenakan, adanya indikator yang memperoleh nilai rata-rata akhir tertinggi seperti daya alam/iklim, hubungan masyarakat, dan juga keindahan, sehingga dapat menutupi rasa ketidaknyamanan wisatawan mancanegara, dan juga dapat menjadi alasan wisatawan mancanegara melakukan kunjungan ulang ke Pantai Kuta. Sehingga, meskipun terdapat beberapa faktor yang menyebabkan wisatawan mancanegara merasa cukup atau kurang nyaman berlibur di Pantai Kuta, mereka tetap berkunjung dan masih tetap merasa nyaman.

Berdasarkan hasil dari pembahasan dapat diketahui bahwa penilaian tertinggi kenyamanan wisatawan mancanegara di Pantai Kuta Bali terletak pada faktor lingkungan yaitu daya alam/iklim mendapatkan perolehan nilai rata-rata terbesar yakni 4.15. Keadaan suhu dan iklim merupakan faktor dominan kenyamanan wisatawan mancanegara yang berkunjung ke Pantai Kuta. Dimana wisatawan khususnya mancanegara, sangat menyukai suhu dan iklim di Kuta untuk berjemur ataupun melakukan aktivitas lainnya. Kebersihan dan keindahan juga menjadi hal terpenting yang membuat wisatawan nyaman untuk berkunjung ke Pantai Kuta.

Interaksi yang terjadi antar wisatawan, dan dengan masyarakat lokal di Kuta juga dipandang sangat baik. Masyarakat lokal yang kebanyakan adalah para penyedia jasa/produk dianggap sangat terbuka dan ramah sehingga tidak jarang masyarakat dan beberapa wisatawan saling berinteraksi dan duduk bersama di tepi pantai. Sehingga dapat disimpulkan bahwa wisatawan mancanegara yang berkunjung ke Pantai Kuta masih merasa nyaman dan Pantai Kuta Bali masih nyaman untuk dikunjungi.

\section{SIMPULAN DAN SARAN Simpulan}

Karakteristik wisatawan mancanegara yang berkunjung atau berlibur ke Pantai Kuta Bali didominasi oleh kunjungan wisatawan laki-laki dengan rentang umur 21-25 tahun. Mayoritas dari wisatawan mancanegara yang berkunjung ke Pantai Kuta saat ini, memiliki latar belakang pekerjaan sebagai Pelajar/Mahasiswa. Dimana, wisatawan yang mendominasi jumlah kunjungan wisatawan mancanegara ke Pantai Kuta Bali yaitu berasal dari Negara Australia.

Berdasarkan hasil perhitungan akhir yang dilakukan secara sistematis, memperoleh 
hasil akhir dengan nilai rata-rata sebesar 3.66, yang nilai tersebut memiliki arti baik. Jika ditarik hasil akhir dan dihubungkan dengan Tabel Interval Kriteria Tingkat Kenyamanan, dapat kesimpulan bahwa persepsi kenyamanan wisatawan mancanegara di Pantai Kuta Bali masuk ke dalam kategori Nyaman. Adapun faktor yang memperoleh nilai tertinggi yakni : Daya alam/iklim, Hubungan masyarakat, Keindahan, Kebersihan, dan Hubungan wisatawan.

\section{Saran}

Saran ini ditujukan kepada pihak pengelola Pantai Kuta Bali, adapun saran yang dapat diberikan adalah hendaknya memberikan ruang yang cukup kepada pengunjung untuk memarkirkan kendaraan ataupun dapat dilakukan rekayasa lalu lintas di daerah padat wisatawan. Sehingga, tidak terjadi kemacetan akibat dari parkir kendaraan sembarangan di sepanjang jalan menuju atau dari Pantai Kuta. Sebagai salah satu indikator yang mendapatkan penilaian terkecil, keamanan di Pantai Kuta hendaknya juga harus ditingkatkan. Keamanan disini seperti peningkatan petugas keamanan, sosialisasi tentang keamanan, serta penambahan informasi mengenai keamanan saat pengunjung beraktivitas di pantai.

Saran akademis ditujukan kepada pihak yang akan melakukan penelitian mengenai kenyamanan wisatawan pada penelitian selanjutnya. Adapun saran yang dapat diberikan adalah hendaknya dapat dilakukan penelitian selanjutnya mengenai kenyamanan di daerah tujuan wisata terkenal atau padat yang lain. Sehingga permasalahan dari setiap industri pariwisata dari sudut kenyamanan dapat segera terselesaikan.

\section{DAFTAR PUSTAKA}

Anonim. 2006. Kamus Besar Bahasa Indonesia. Departemen Pendidikanan Nasional. Jakarta: Balai Pustaka.

Kolbaca, Katharine, DiMarco, Marguerite. 2005. Comfort theory and its application to pediatric nursing. A Pediatric nursing.

Rhesyana R, Binar. 2014. Persepsi Pengunjung Taman Terhadap Tingkat Kenyamanan Taman-taman di Kota Banjarnegara Sebagai Ruang Publik
(Skripsi). Semarang : Universitas Negeri Semarang. 